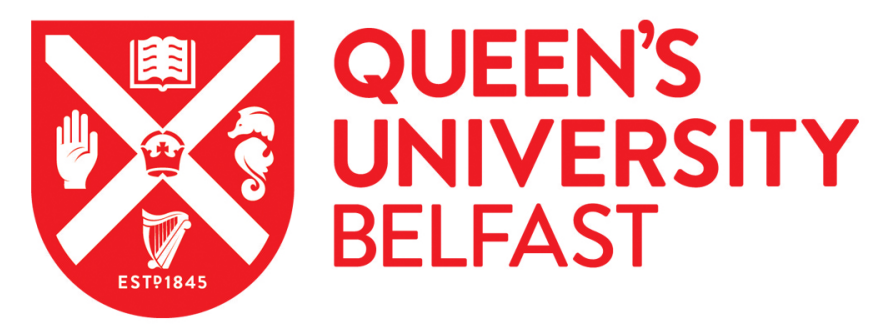

\title{
Effect of laser treatment on the attachment and viability of mesenchymal stem cell responses on shape memory NiTi alloy
}

Chan, C. W., Hussain, I., Waugh, D. G., Lawrence, J., \& Man, H. C. (2014). Effect of laser treatment on the attachment and viability of mesenchymal stem cell responses on shape memory NiTi alloy. Materials Science and Engineering C: Materials for Biological Applications, 42, 254-263.

https://doi.org/10.1016/j.msec.2014.05.022

Published in:

Materials Science and Engineering C: Materials for Biological Applications

Document Version:

Peer reviewed version

Queen's University Belfast - Research Portal:

Link to publication record in Queen's University Belfast Research Portal

Publisher rights

Copyright 2014 Elsevier.

This manuscript version is made available under the CC-BY-NC-ND 4.0 license (http://creativecommons.org/licenses/by-nc-nd/4.0/).

\section{General rights}

Copyright for the publications made accessible via the Queen's University Belfast Research Portal is retained by the author(s) and / or other copyright owners and it is a condition of accessing these publications that users recognise and abide by the legal requirements associated with these rights.

Take down policy

The Research Portal is Queen's institutional repository that provides access to Queen's research output. Every effort has been made to ensure that content in the Research Portal does not infringe any person's rights, or applicable UK laws. If you discover content in the Research Portal that you believe breaches copyright or violates any law, please contact openaccess@qub.ac.uk. 


\title{
Effect of Laser Treatment on the Attachment and Viability of Mesenchymal Stem Cell Responses on Shape Memory NiTi Alloy
}

\author{
C.W. Chan ${ }^{a^{*}}$, I. Hussain ${ }^{\text {b }}$ D.G. Waugh ${ }^{\text {c }}$ J. Lawrence ${ }^{\mathrm{c}}$, H.C. Man ${ }^{\mathrm{d}}$ \\ ${ }^{a}$ School of Mechanical and Aerospace Engineering, Queen's University Belfast, Northern Ireland, UK \\ ${ }^{\mathrm{b}}$ School of Life Sciences, University of Lincoln, Brayford Pool, Lincoln, Lincolnshire, LN6 7TU, UK \\ ${ }^{c}$ School of Engineering, University of Lincoln, Brayford Pool, Lincoln, Lincolnshire, LN6 7TU, UK \\ ${ }^{\mathrm{d}}$ Department of Industrial and Systems Engineering, The Hong Kong Polytechnic University, Hung Hom, \\ Kowloon, Hong Kong, China
}

\begin{abstract}
The objectives of this study were to investigate the effect of laser-induced surface features on the morphology, attachment and viability of mesenchymal stem cells (MSCs) at different periods of time, and to evaluate the biocompatibility of different zones: laser-melted zone (MZ), heat-treated zone (HAZ) and base metal (BM) in laser-treated NiTi alloy. The surface morphology and composition were studied by SEM (in BSE mode) and XPS, respectively. The cell morphology was examined by SEM (in SE mode) while the cell counting and viability measurements were done by haemocytometer and MTT assay. The results indicated that the laser-induced surface features, such as surface roughening, presence of anisotropic dendritic pattern and complete surface $\mathrm{Ni}$ oxidation were beneficial to improve the biocompatibility of NiTi as evidenced by the highest cell attachment and viability found in the MZ. The biocompatibility of the MZ was the best, followed by the BM with the HAZ being the worst.

*E-mail address of corresponding author: c.w.chan@qub.uk.ac

*Tel. of corresponding author: $+\underline{44(0) 2890974905}$
\end{abstract}




\section{Introduction}

In the last decades, NiTi alloys have been widely used in bio-medical areas for cardiovascular, orthopedic and dental applications and for making advanced surgical instruments because of the shape-memory effect (SME), superelasticity (SE) and fairly good biocompatibility $[1,2]$. One concern of NiTi for bio-implant applications is the presence of toxic $\mathrm{Ni}$ in the surface layer [3]. Excessive amount of $\mathrm{Ni}$ release can cause allergic reactions and biocompatibility problems including chronic sinusitis and rhinitis, nostril and lung cancer for patients [4-6]. Moreover, Sun et al. [7] showed that even at subtoxic concentrations, Ni ions can alter osteoblast behaviour and cause a significant decrease in alkaline phosphatase activity (ALP, an early marker of osteoblastic differentiation) as well as DNA synthesis. In consideration of this, surface treatment of $\mathrm{NiTi}$ implants for reducing $\mathrm{Ni}$ release is therefore necessary. Among different surface treatment methods that have been reported, laser surface treatment is particularly suitable for treating NiTi on account of (1) the production of the rapidly re-solidified surface layer with more homogeneous microstructure and higher concentration of $\mathrm{TiO}_{2}[8,9]$ and (2) the localization of heat energy at only the surface level, leaving the bulk properties unaffected $[10,11]$. Even though the corrosion and Ni release behavior of laser-treated NiTi surface is found to be greatly improved comparing with the untreated surface, the effect of laser-induced surface features on the biocompatibility, particularly the cell responses in vitro, is still far from being fully understood. Furthermore, it is important to note that the heat-affected zone (HAZ) is always present between the laser-treated and untreated surfaces, but its effect on the biocompatibility of NiTi has never been reported. 
It has been reported that in vivo conditions, the major contribution to bone defect filling and tissue repair is derived from the newly differentiated osteoblast cells rather than directly from pre-existing osteoblasts [12]. Therefore, the potential of mesenchymal stem cells (MSCs) to differentiate into osteoblast cells while adhering onto the biomaterial surfaces make them favorable for bone tissue engineering [13, 14]. Campoccia et al. [12] stated that the ideal osteocompatible biomaterial surfaces should exhibit the following characteristics in vitro: (1) allow good and tight initial adhesion, (2) support cell attachment and viability, and (3) have a positive influence upon the differentiation process. In the authors' previous study [15], good initial adhesion of MSCs was found on the laser-treated surface. Recent study [16] showed that laser-induced surface features can accelerate the adhesion and proliferation of osteoblast cells, but it is still unknown whether such good effect can extend to the attachment and viability of MSCs because the cellular responses are varying with different cell types. For example, osteoblast cells prefer rough surfaces while fibroblast cells prefer smooth surfaces $[17,18]$. In this study, the objectives were to investigate the effect of the laser-induced surface features on the morphology, attachment and viability of MSCs at different periods of time, and to evaluate the biocompatibility of different zones: laser-melted zone (MZ), heat-treated zone (HAZ) and base metal $(\mathrm{BM})$ in the laser-treated NiTi alloy. The possibility to modulate the osteoblastic differentiation by laser surface treatment was also discussed. 


\section{Materials and Methods}

\section{Laser Surface Treatment}

The material was flat annealed $\mathrm{Ti}-55.91$ wt. \% Ni foil of thickness $0.25 \mathrm{~mm}$ (Johnson Matthey, Inc.). The samples were ultrasonically degreased in pure alcohol for $10 \mathrm{~min}$, followed by 5 min of cleaning in distilled water, and dried thoroughly in air before the laser treatment. A 100-W continuous wave (CW) fiber laser (SP-100C-0013; SPI and A\&P Co., Ltd.) with a wavelength of $1091 \mathrm{~nm}$ was used for the laser treatment under argon shielding environment. The process parameters were optimized by a fractional factorial experimental design [19] and the optimized parameters were: $70 \mathrm{~W}$ (laser power), $300 \mathrm{~mm} / \mathrm{min}$ (scanning speed), $+1.6 \mathrm{~mm}$ (away from the top surface of samples, focus position), $35 \mathrm{~L} / \mathrm{min}$ (flow rate) and under Ar (shielding environment).

\section{Sample Preparation}

The cell morphology study on the surface of NiTi was carried out on laser-treated samples comprising MZ, HAZ and BM cultured in a 24-well plate. Single laser track was formed on a NiTi foil (surface area of $5 \times 10 \mathrm{~mm}^{2}$ ), with the HAZ and BM in the adjacent area. Each of the zones (MZ, HAZ and BM) approximately contributed to one-third of the total surface area. The effect of surface roughness on the cell morphology was studied by comparing the surfaces with and without grinding/polishing (with sandpapers from 180-grit to 2400-grit). On the other hand, 
the laser-melted zone (MZ) with and without grinding/polishing, heat-treated zone (HAZ) and base metal $(\mathrm{BM})$ were carefully cut from the laser-treated samples by diamond cutter, and individually cultured in 96-well plates for the cell counting and viability measurements. The surface roughness parameters of different samples: MZ (as-treated), MZ (ground), MZ (polished), HAZ and BM have been measured in our previous work [15] and are summarized in Table 1 in this study.

\section{Surface Morphology and Composition}

The surface morphology of different samples was studied in the backscattered electron (BSE) mode by scanning-electron microscopy (SEM, Model JSM-6490) equipped with energy-dispersive X-ray (EDX) detector for elemental mapping. The surface composition of the samples was analyzed by X-ray photoelectron spectroscopy (XPS, Kratos Axis Ultra DLD Spectrometers) using monochromatic $\mathrm{Al}$ radiation at $12 \mathrm{~mA}$ x $12 \mathrm{kV}$. The photoelectron emission was at normal emission (sample flat under the analyzer). The pass energy for high resolution scan and survey scan spectra were $40 \mathrm{eV}$ and $160 \mathrm{eV}$ respectively. The spectra were acquired in the hybrid collection mode of the spectrometer which used both electrostatic and magnetic lenses to improve sensitivity. The analyzed region was an approximate area of $700 \times 300$ microns. 


\section{Cell Culture}

A research laboratory safety protocol was followed. To avoid contamination of the cells, the culture work was conducted within a Class II Microbiological Safety Cabinet, and sterile conditions were maintained. All used items were correctly discarded in accordance with the laboratory safety protocol. Mesenchymal stem cells (MSCs, Stem Cell Bank, Japan) were grown in tissue culture medium consisting of DMEM (with L-glutamine) (Sigma Aldrich, Ltd.), supplemented with $10 \%$ fetal calf serum (FCS) (Sigma Aldrich, Ltd.), and 100 units/ml of penicillin and 0.1-mg/ml of streptomycin (Sigma Aldrich, Ltd.), and placed in an incubator set at $37{ }^{\circ} \mathrm{C}, 5 \%$ humidified $\mathrm{CO}_{2}$ (Wolf Laboratories, Ltd.), throughout the study. When the cells reached subconfluent (70 to $80 \%$ ), they were retrieved with $0.25 \%$ trypsin and $0.02 \%$ EDTA. The retrieved cells were washed twice with PBS, centrifuged at $1200 \mathrm{rpm}$ for $12 \mathrm{~min}$ at room temperature and re-seeded onto the samples which had been placed in the 24- and 96-well plates. The cells were seeded at the initial density of $5 \times 10^{4}$ cells per $\mathrm{cm}^{2}$ and maintained under the same culture conditions mentioned before [20] at different periods of time.

\section{Cell Morphology}

The cell morphology on different samples after 1 and 4 days of culture was analyzed in the secondary electron (SE) mode by the SEM. The following procedure was undertaken to produce a sample that was dehydrated ready for Au coating. After removal of the culture media, the 
samples were initially rinsed with phosphate-buffered saline (PBS) (Sigma-Aldrich, Ltd.) to remove any unattached cells and then adherent cells were fixed using $1.2 \%$ glutaraldehyde in water (Sigma-Aldrich, Ltd.) at room temperature for an hour within the BSC. After an hour the glutaraldehyde solution was removed and the fixed cells were washed with PBS prior to carrying out a graded series of ethanol/distilled water mixtures of $50 \%, 80 \%, 90 \%, 95 \%, 98 \%$ and 100 $\%$. Each sample was left in these mixtures for $10 \mathrm{~min}$ and dried in air. The samples were sputter coated with Au for cell morphology observation by SEM.

\section{Cell Counting}

The number of viable cells on different samples after 1 and 4 days of culture was counted in a 25-square of the haemocytometer (Neubauer Improved Bright Line at depth $0.1 \mathrm{~mm}, 0.00025$ $\mathrm{mm}^{3}$ ). Trypan blue was used as the dye to stain the cells. $50 \mu \mathrm{l}$ of homogeneous cell suspension, in tissue culture medium consisting of DMEM (with L-glutamine) (Sigma Aldrich, Ltd.), supplemented with $10 \%$ foetal calf serum (FCS) and 100 units $/ \mathrm{ml}$ of penicillin and $0.1 \mathrm{mg} / \mathrm{ml}$ of streptomycin (Sigma Aldrich, Ltd.), was added to $50 \mu$ of $0.4 \%$ trypan blue (Sigma). This was repeated for two chambers and the mean number of viable cells was obtained, and the following equation was applied: Number of cells $/ \mathrm{ml}=$ mean number of cells $\times 2$ (dilution factor) $\times 10^{4}$. 


\section{Cell Viability}

The cell viability on different samples after 1, 4 and 7 days of culture was determined by 3-(4,5-dimethylthiazol-2-yl)-2,5-diphenyltetrazolium bromide (MTT) colorimetric assay. Mesenchymal stem cell line was cultured, harvested, resuspended and counted by haemocytometer. Duplicate cells were pipetted into the wells of separate 96-well microplates each containing $100 \mu \mathrm{ls}$ of previously pipetted complete culture medium and the NiTi samples. Control samples containing equal amount of cells and complete culture medium and a set of blanks containing complete culture medium only (100 $\mu$ ls/well) were also prepared.

After 1, 4, and 7 days, the complete media was removed and $50 \mu$ ls of MTT reagent (10 $\mathrm{mg} / \mathrm{ml}$ dissolved in media) was added to cells for 4 hours and incubated in the dark. The MTT reagent was then expelled and $100 \mu \mathrm{ls}$ of Dimethyl sulfoxide (DMSO) was added to cells to dissolve the purple formazan product. Afterwards, the optical density of all wells was measured at $570 \mathrm{~nm}$ using a 96-well microplate reader (FLUOstar OPTIMA Microplate Reader, Germany). The average values for the three readings of each sample were determined. The optical density of the solution is a measure of the cell viability/living cell count on a surface in the MTT assay. A higher optical density indicates a higher concentration of living cells [21]. 


\section{Statistical analysis}

The significance of the observed differences between the means of different samples was tested by Student t-test using SPSS software, version 16 (SPSS, Inc.). The probability below p < 0.05 was considered as statistically significant. 


\section{Surface Morphology Analysis by SEM (in Backscatter Electron Mode)}

The surface morphology of the MZ, MZ/HAZ boundary and BM is examined by SEM in the backscatter electron mode and the SEM images are given in Fig. 1 (a-c). Fig. 1 (a) shows the SEM image for the MZ, while Fig. 1 (b) and (c) give the images for the MZ/HAZ boundary and $\mathrm{BM}$ respectively. The corresponding distribution of $\mathrm{Ti}$ and $\mathrm{Ni}$ at the $\mathrm{MZ}, \mathrm{MZ} / \mathrm{HAZ}$ boundary and BM are captured by EDS mapping analysis. The mapping images are shown alongside the SEM images in Fig. 1 (a-c).

As can be observed in Fig. 1 (a), the MZ showed an anisotropic dendritic pattern in the surface which is a typical feature of laser surface melting. In Fig. 1 (b), a clear fusion boundary can be found between the surfaces at the MZ and HAZ. When comparing with the MZ (in the left), some surface defects such as pores and cracks were found in the surface of HAZ. The SEM image in Fig. 1 (c) showed that the surface morphology of BM was similar to that of the HAZ. Some obvious pores can be seen in the surface of BM. When looking at the mapping images in Fig. 1 (b), the distribution of $\mathrm{Ti}$ (or Ni) at the MZ and HAZ was more or less the same that it was evenly distributed throughout the surfaces. No obvious surface particles or inclusions can be found in the MZ and HAZ. Similar observations can also be found in the mapping images of BM, as given in Fig. 1 (c). 


\section{Surface Composition Analysis by XPS}

The XPS 2p spectra of Ti and Ni for different samples are given in Fig. 2 (a-e) and 3 (a-e) respectively. The relative percentage (at.\%) of the metallic species in the oxide layer is given in Table 2 . The background in the Ti $2 \mathrm{p}$ and $\mathrm{Ni} 2 \mathrm{p}_{3 / 2}$ spectra were fixed by the Shirley method. Deconvolution of the Ti $2 \mathrm{p}$ spectra was performed by four oxidation states, namely $\mathrm{Ti}^{0}$ (metallic Ti), $\mathrm{Ti}^{2+}(\mathrm{TiO}), \mathrm{Ti}^{3+}\left(\mathrm{Ti}_{2} \mathrm{O}_{3}\right)$ and $\mathrm{Ti}^{4+}\left(\mathrm{TiO}_{2}\right)$, with corresponding $2 \mathrm{p}^{3 / 2}$ peaks at $454.2,455.4,457.5$ and $459.2 \mathrm{eV}$, and $2 \mathrm{p}^{1 / 2}$ peaks at 460.7, 461.9, 463.4 and $464.9 \mathrm{eV}$. It could be observed from Fig. 2 that the $\mathrm{Ti}$ species at the surface of the samples was predominantly $\mathrm{TiO}_{2}$ with minor metallic $\mathrm{Ti}$, $\mathrm{TiO}$ and $\mathrm{Ti}_{2} \mathrm{O}_{3}$. Deconvolution of the $\mathrm{Ni} 2 \mathrm{p}^{3 / 2}$ spectra was accomplished by three oxidation states, namely $\mathrm{Ni}^{0}$ (metallic $\left.\mathrm{Ni}\right), \mathrm{Ni}^{2+}(\mathrm{NiO})$ and $\mathrm{Ni}^{3+}\left(\mathrm{Ni}_{2} \mathrm{O}_{3}\right.$ or $\left.\mathrm{Ni}(\mathrm{OH})_{2}\right)$ with corresponding peaks at $852.9,854.6$ and $856.5 \mathrm{eV}$. It is important to note that the peak at $856.5 \mathrm{eV}$ can be attributed by either $\mathrm{Ni}_{2} \mathrm{O}_{3}$ or $\mathrm{Ni}(\mathrm{OH})_{2}$. As reported by Briggs and Seah [22], $\mathrm{Ni}_{2} \mathrm{O}_{3}$ is unlikely to be present in practical situation because it is unstable. The peak was therefore interpreted as $\mathrm{Ni}(\mathrm{OH})_{2}$ in this study. Furthermore, the second peak which occurs at a higher binding energy, $861.8 \mathrm{eV}$ is the shake-up satellite of $\mathrm{Ni}(\mathrm{OH})_{2}$ [23]. From the curve fitting of the peaks in Fig. 3, the Ni at the surface was mainly composed of $\mathrm{Ni}(\mathrm{OH})_{2}$ with a small amount of $\mathrm{NiO}$ and metallic $\mathrm{Ni}$.

Looking at the relative concentration (at.\%) of $\mathrm{Ti}$ and $\mathrm{Ni}$ species in the oxide layer, the results of calculations in Table 2 show that the oxide layer of the MZ (as-treated) was still predominantly $\mathrm{TiO}_{2}(77.11$ at.\%) with some $\mathrm{Ti}$ sub-oxides and $\mathrm{Ni}$ oxidized species, but no 
metallic Ni was detected. All the other samples show a similar result, with the oxide layers dominated by $\mathrm{TiO}_{2}$ with a concentration varying from 60.15 at.\% to 71.66 at.\%. However, a small amount of metallic Ni started to appear in the HAZ, and become highest in MZ (polished). The free energy for the formation of $\mathrm{Ti}$ oxides is lower than the $\mathrm{Ni}$ oxides, and therefore thermodynamically the oxidation of $\mathrm{Ti}$ is strongly preferred over the oxidation of $\mathrm{Ni}$. Consequently, $\mathrm{TiO}_{2}$ contributed to the highest concentration in the oxide layer. The absence of metallic $\mathrm{Ni}$ in $\mathrm{MZ}$ (as-treated) could be explained by the complete surface $\mathrm{Ni}$ oxidation $\left(\mathrm{Ni}^{3+}\right)$ due to the very fast oxidation at high temperature during laser treatment [24]. It has been reported that extra fast oxidation at sufficiently high temperature is favorable for the formation of a fully stabilized $\mathrm{TiO}_{2}$ layer without $\mathrm{Ti}$ sub-oxides, thus avoiding $\mathrm{Ni}$ atoms remaining in the latter and yielding the oxide layers without $\mathrm{Ni}$ atoms or particles [25]. Similarly, the elevated temperature in the $\mathrm{HAZ}$ promoted the oxidation of $\mathrm{Ni}$ and therefore the metallic $\mathrm{Ni}$ at the surface was relatively depleted when comparing with the BM. It is worthwhile to note that metallic Ni was found in the MZ (ground) and MZ (polished). This is probably because the higher stress state induced by mechanical polishing causes the outward diffusion of Ni to the surface [26, 27].

The surface composition (at.\%) for different samples is given in Table 3. It is common in surface XPS scans that a high concentration of $\mathrm{C}$ is present due to environmental contamination. From the results in Table 3, the MZ (as-treated) shows the lowest Ni/Ti ratio, followed by the HAZ, MZ (ground), BM, with MZ (polished) having the highest Ni/Ti ratio. The surface Ni/Ti 
ratio is a crucial parameter to indicate the Ni release potential to the surrounding tissues at the beginning of implantation for NiTi implants [28]. However, only the surface Ni/Ti ratio is not enough to make a comprehensive judgment about the safety of NiTi implants because metallic $\mathrm{Ni}$ atoms can exist and diffuse easily through the defective Ti sub-oxides [29]. Furthermore, Shabalovskaya and Anderegg [3] pointed out that the $\mathrm{Ni}^{2+}$ release from metallic $\mathrm{Ni}$ is more toxic than the $\mathrm{Ni}^{3+}$. Consequently, it is more appropriate to determine the degree of safety of NiTi implants based on the $\mathrm{Ni} / \mathrm{TiO}_{2}$ ratio together with the surface $\mathrm{Ni} / \mathrm{Ti}$ ratio. $\mathrm{The} \mathrm{Ni} / \mathrm{TiO}_{2}$ ratio is given in Table 2, and the results are in good agreement with that of $\mathrm{Ni} / \mathrm{Ti}$ ratio, with $\mathrm{MZ}$ (as-treated) showing the lowest $\mathrm{Ni} / \mathrm{TiO}_{2}$ ratio and $\mathrm{MZ}$ (polished) showing the highest. Therefore, the lowest surface $\mathrm{Ni} / \mathrm{Ti}$ and metallic $\mathrm{Ni} / \mathrm{TiO}_{2}$ ratios in $\mathrm{MZ}$ (as-treated) would indicate that it is biologically safer than the other samples. 


\section{Cell Morphology Analysis by SEM (in Secondary Election Mode)}

Initial cell adhesion for 4 hours of culture was captured by SEM, and the corresponding SEM images for different samples are given Fig. 4 (a-d). Only the SEM images for the BM are shown, but not the HAZ, given their similar surface topography and roughness. It can be observed from Fig. 4 (b-d) that the cells on MZ (ground), MZ (polished), and BM show round morphology and are more isolated from each other. On the contrary, Fig. 4 (a) shows that some cells on the MZ (as-treated) still retain the round shape, but most of the cells spread across the surface and form colonies between them (as indicated by the dashed arrows). Fig. 5 (a-b) shows the magnified SEM images (pointed by the arrow in Fig. 4 (a)) for the cell stretching out to interconnect to its neighboring cell on the MZ (as-treated). Such observation points to the fact that the cell spreading process is already starts at 4 hours of incubation on MZ (as-treated). It is worthwhile to mention that the cells would like to seed on the distinctive surface features, such as groove, pores, and dendritic pattern rather than on the plain area, and this phenomenon has been discussed in details in the authors' previous study [15].

The morphology of cells after 1 day of culture on different samples is given in Fig. 6 (a-d). In Fig. 6 (b-d), most of the cells show a spreading morphology with cytoplasmic projections on the BM, MZ (ground) and MZ (polished), but some cells still retain their round morphology (as pointed by the arrows). The cells on MZ (as-treated) have spread completely and no round cell is seen on the surface. Particularly, in the magnified SEM image given in Fig. 7, well-developed 
intercellular junctions and numerous cytoplasmic projections can be found in the cells cultured on MZ (as-treated). It indicates that the cells after 1 day of culture adapt well to the surface of MZ (as-treated) when comparing with the other samples.

\section{Cell Counting Measurement by Haemocytometer}

The number of viable cells on different samples after 1 and 4 days of culture is plotted in Fig. 8. From the results, MZ (as-treated) shows a higher number of cells compared with MZ (polished) and HAZ for all culture periods and the BM after 4 days of culture. Statistical analysis reveals that significant differences $(\mathrm{p}<0.05)$ in the cell number are present between $\mathrm{MZ}$ (as-treated) and MZ (polished) or HAZ or BM. No statistical difference can be found between the cell number of MZ (as-treated) and MZ (ground). The cell number of MZ (ground) is significantly higher $(\mathrm{p}<0.05)$ than the HAZ and MZ (polished) for all culture periods. Similarly, the $\mathrm{BM}$ shows a higher cell number than the HAZ for all culture periods and MZ (polished) after 4 days of culture with statistical significances $(\mathrm{p}<0.05)$.

\section{Cell Viability Measurement by MTT Assay}

The cell viability on different samples after 1, 4 and 7 days of culture is plotted in Fig. 8 .

The results in Fig. 8 show that the cell viability of MZ (as-treated) is higher than MZ (polished),

HAZ and BM for all incubation periods and the differences are statistically significant $(\mathrm{p}<0.05)$. 
MZ (as-treated) shows a significantly higher cell viability $(\mathrm{p}<0.05)$ than MZ (ground) cultured for 7 days. The cell viability of MZ (ground) and BM is both significantly higher $(\mathrm{p}<0.05)$ than the HAZ for all culture periods and MZ (polished) cultured for 4 and 7 days. To sum up the results in the cell count and viability measurements, MZ (as-treated) shows the best biocompatibility as evidenced by the highest cell number and viability, followed by MZ (ground) or BM, with MZ (polished) or HAZ being the least.

\section{Evaluation of Cell Attachment and Viability}

Cell attachment is an important parameter to determine the suitability of implant surfaces for medical applications. A stable connection between the biomaterial surface and the surrounding tissues is a prerequisite for the long term success of NiTi implants [30]. It is known that the cell attachment is primarily associated with the material surface characteristics, such as surface topography, roughness, chemistry and wettability [31].

First, the quality of the connection between cells and biomaterials is primarily determined by surface topography [30]. MSCs are more likely to adhere and grow on an organized surface due to the presence of contact guidance for cells to align and orient along with a defined direction [15]. Cell attachment was reported to be lower on a less organized surface [32]. Second, surface roughness increases the protein adsorption and amount of surface area [33]. It has been reported that the total protein adsorbed on the rougher surface is greater than that on the smooth 
surface [34, 35]. Higher absorption of protein, particularly fibronectin, is beneficial for enhancing the attachment of MSCs [34]. Moreover, the increased amount of surface area can provide more anchorage points available for the cells to interact initially with the materials [36]. Third, the stability of NiTi in biological environments is due to the simultaneous formation of $\mathrm{TiO}_{2}$-based surface layer which is a few nanometers thick. $\mathrm{TiO}_{2}$ is a known biocompatible material and cell adhesion on $\mathrm{TiO}_{2}$ can promote the increased attachment of MSCs [36]. However, as discussed in the earlier section, metallic $\mathrm{Ni}$ in the oxide layer of NiTi is toxic to the cells. It is believed that the lower $\mathrm{Ni} / \mathrm{TiO}_{2}$ ratio in the oxide layer, the better the cell attachment on the substrate. Fourth, it is known that cell attachment is better on a hydrophilic surface than a hydrophobic surface [37-39]. Yang et al. [40] showed that MSCs seeded on a more hydrophilic surface adopted an earlier spread-up morphology and resulted in increased attachment. Surface topography and roughness play a crucial role in the wetting behaviour, with more organized surface and higher surface roughness presenting a more hydrophilic behaviour on Ti alloys [35, 41]. Laser surface treatment has been reported to be an efficient technique to control the wetting behavior, with the laser-treated surfaces being more hydrophilic than the non-treated surfaces [16, 41].

Based on the above reasons, the highest cell attachment and viability measured in $\mathrm{MZ}$ (as-treated) can be attributed to the synergistic effect of the highest surface roughness, lowest surface $\mathrm{Ni} / \mathrm{TiO}_{2}$ ratio, and presence of the anisotropic dendritic pattern. However, the effect of 
laser-induced surface features on the wetting behavior is still inconclusive. An ongoing study in the wetting behavior of laser-treated surface on the cell responses is being conducted in line with this research. It is important to note that the cells were cultured at $37^{\circ} \mathrm{C}$ which is well above the austenite finish temperatures of all the samples. Therefore, the samples were in pure austenite phase throughout the study and the effect of phase switching on the cell attachment and viability can be neglected. On the other hand, the findings in this study are in good agreement with literature results that the rougher samples: MZ (as-treated), MZ (ground), and BM, show higher cell attachment and viability than that of the smoother sample: MZ (polished) [21, 31, 36, 42].

It is of particular interest to note that the HAZ has moderately high roughness and low surface $\mathrm{Ni} / \mathrm{TiO}_{2}$ ratio, but the cell attachment and viability is comparable to $\mathrm{MZ}$ (polished) which has a smooth surface and high surface $\mathrm{Ni} / \mathrm{TiO}_{2}$. This is most likely a result of the microstructural defects present in the oxide layer and grain structure of the HAZ. First, heat conduction through NiTi during laser treatment removes the effect of prior thermo-mechanical history and results in re-crystallization in the $\mathrm{HAZ}$, analogous to the heat-treatment process between 600 and $800{ }^{\circ} \mathrm{C}$ [43]. The heat-treatment of NiTi in such temperature range leads to the formation of a defective and porous black oxide layer which promotes the outward Ni diffusion [44]. Defects such as voids or vacancies provide pathways for metallic Ni to diffuse from the nickel-rich underneath layers to the surface and thereby leak to the cell culture medium causing harmful effects to the cells. On the contrary, the oxide formed on the laser-melded surface is clean and compact [45]. 
Such results indicate that the quality and compactness of oxide layer should be considered together with the $\mathrm{Ni} / \mathrm{TiO}_{2}$ ratio when determining the degree of safety for NiTi implants. Second, the cell attachment was reported to be grain-size dependent. Finer grains are more favorable for the cell attachment than the coarser grains $[46,47]$. Therefore, the defective and porous oxide layer as well as the coarse grained structure might attribute to the inferior cell attachment and viability on the HAZ compared with the BM which has similar surface morphology. 


\section{Possibility to Modulate the Osteoblastic Differentiation}

The osteoblastic differentiation of MSCs is highly regulated by micro-environmental factors such as extracellular matrix (ECM) and substrate surface geometry [48-53]. MSCs would form different focal attachments on a less organized surface and result in a phenotype district from that on a more organized surface even with the same degree of roughness [54]. Recent research $[15,16,41]$ pointed out that anisotropic texture on the laser-treated surface can provide topographical cues to induce contact guidance of cells. Such responses involve substantial cytoskeletal reorganization, which is known as a prerequisite to stimulate MSCs differentiation into an osteoblastic lineage [55-57]. Consequently, it is possible to modulate the cellular responses of MSCs by the optimization of laser parameters to obtain the surface with optimized combinations of surface topography, roughness and wettability for triggering the osteoblastic differentiation. 


\section{Conclusions}

The effect of laser-induced surface features on the morphology, attachment and viability of MSCs at different periods of time was investigated. The biocompatibility of different zones (MZ, HAZ and BM) in the laser-treated NiTi alloy was also evaluated and compared. The following observations were made in this study.

1. The SEM (in BSE mode) results show that the MZ exhibited an anisotropic dendritic pattern in the surface whereas the surface morphology of the HAZ and BM was similar with some surface defects, such as pores and cracks;

2. The XPS results indicate that the oxide layers on different zones were predominantly $\mathrm{TiO}_{2}$ with some Ti sub-oxides and Ni oxidized species. Small amount of metallic Ni was found in the BM and HAZ, whereas no metallic Ni was present in the MZ;

3. The SEM (in SE mode) results show that the cells cultured on the MZ had a more spread morphology compared with that on the HAZ and BM;

4. The MZ showed the highest cell attachment and viability compared with the HAZ and BM. Such improvement can be attributed to the synergistic effect of the highest surface roughness, lowest surface $\mathrm{Ni} / \mathrm{TiO}_{2}$ ratio and presence of the anisotropic dendritic pattern;

5. The HAZ exhibited a lower cell attachment and viability in comparison to the BM, possibly due to the microstructural defects present in the oxide layer and grain structure of the HAZ. 


\section{References}

1. T. Duerig, A. Pelton, D. Stockel, An overview of Nitinol medical applications, Materials Science and Engineering A, 273-275 (1999) 149-160.

2. N.B. Morgan, Medical shape memory alloy applications - the market and its products, Materials Science and Engineering A, 378 (2004) 16-23.

3. S.A. Shabalovskaya, J.M. Anderegg, Surface spectroscopic characterization of TiNi equiatomic shape memory alloys for implants, Journal of Vacuum and Science Technology A, 13 (1995) 2624-2632.

4. D. Mantovani, Shape memory alloys: properties and biomedical applications. JOM Journal of the Minerals, Metals and Materials Society, 52 (2000) 36-44.

5. A. Kapanen, J. Ryhanen, A. Danilova, J. Tuukkanena (2001). Effect of nickel-titanium shape memory metal alloy on bone formation, Biomaterials, 22 (2001) 2475-2480.

6. L.G. Machado, M.A. Savi, Medical applications of shape memory alloys, Brazilian Journal of Medical and Biological Research, 36 (2003) 683-691.

7. Z.L. Sun, J.C. Wataha, C.T. Hanks, Effects of metal ions on osteo-like cell metabolism and differentiation, Journal of Biomedical Materials Research, 34 (1997) 29-37.

8. H.C Man, Z.D Cui, T.M Yue, Corrosion properties of laser surface melted NiTi shape memory alloy, Scripta Materialia, 45 (2001) 1447-1453.

9. Z.D. Cui, H.C. Man, X.J. Yang, The corrosion and nickel release behavior of laser surface-melted NiTi shape memory alloy in Hanks' solution, Surface and Coatings Technology, 192 (2005) 346-353.

10. M.H. Wong, F.T. Cheng, H.C. Man, Laser oxidation of NiTi for improving corrosion resistance in Hanks' solution, Materials Letters, 61 (2007) 3391-3394.

11. M.H. Wong, F.T. Cheng, G.K.H. Pang, H.C. Man, Characterization of oxide film formed on NiTi by laser oxidation, Materials Science and Engineering A, 448 (2007) 97-103. 
12. D. Campocciaa, C.R. Arciolaa, M. Cervellatia, M.C. Maltarelloc, L. Montanaro, In vitro behaviour of bone marrow-derived mesenchymal cells cultured on fluorohydroxyapatite-coated substrata with different roughness, Biomaterials, 24 (2003) 587-596.

13. H. Petite, V. Viateau, W. Bensaid, A. Meunier, C. dePollak, M. Bourguignon, K. Oudina, L. Sedel, G. Guillemin, Tissue-engineered bone regeneration, Nature Biotechnology, 18 (2000) 959-963.

14. R. Cancedda, G. Bianchi, G. Cancedda Bianchi, A. Derubeis, R. Quarto, Cell therapy for bone disease: a review of current status, Stem Cells, 21 (2003) 610-619.

15. C.W. Chan, I. Hussain, D.G. Waugh, J. Lawrence, H.C. Man, In vitro mesenchymal stem cell responses on laser-welded NiTi alloy, Materials Science Engineering C, 33 (2013) $1344-1354$

16. C. Liang, H. Wang, J. Yang, B. Li, Y. Yang, H. Li, Biocompatbility of the micro-patterned NiTi surface produced by femotosecond laser, Applied Surface Science, 261 (2012) 337-342.

17. C. Wirth, V. Comte, C. Lagneau, P. Exbrayat, M. Lissac, N. Jaffrezic-Renault, L. Ponsonnet, Nitinol Surface roughness modulates in vitro cell response: a comparison between fibroblasts and osteoblasts, Materials Science Engineering C, 25 (2005) 51-60.

18. T.P. Kunzler, C. Huwiler, T. Drobek, J. Voros, N.D. Spencer, Systematic study of osteoblast response to nanotopography by means of nanoparticle-density gradients, Biomaterials, 28 (2007) 5000-5006.

19. C.W. Chan, H.C. Man, Laser welding of thin foil nickel-titanium shape memory alloy, Optics and Lasers in Engineering, 49 (2011) 121-126.

20. I. Hussain, S.A. Magd, O. Eremin, M. El-Sheemy, New approach to isolate mesenchymal stem cell (MSC) from human umbilical cord blood, Cell Biology International, 36 (2012) 595-600.

21. M. Bigerelle, S. Giljean, K. Anselme, Exitence of a typical threshold in the response of human mesenchymal stem cells of a peak and vally topography, Acta Biomaterialia, 7 (2011) 3302-3311. 
22. D. Briggs, M.P. Seah, Practical Surface Analysis, 2nd ed., Vol. 1, Auger and X-ray Photoelectron, Wiley, Chichester, UK, 1990, p. 635.

23. D.A. Armitage, D.M. Grant, Characterisation of surface-modified mickel titanium alloys, Materials and Science Engineering A, 349 (2003) 89-97.

24. S.A. Shabalovskaya, J.M. Anderegg, Surface spectroscopic characterization of TiNi equiatomic shape memory alloys for implants, Journal of Vacuum and Science Technology A, 13 (1995) 2624-2632.

25. H. Tian, D. Schryvers, D. Liu, Q. Jiang, J.V. Humbeeck, Stability of Ni in Nitinol oxide surfaces, Acta Biomaterialia, 7 (2011) 892-899.

26. S. Trigwell, R.D. Hayden, K.F. Nelson, G. Selvaduray, Effects of surface treatment on the surface chemistry of NiTi alloy for biomedical applications, Surface and Interface Analysis, 26 (1998) 483-489.

27. L. Ponsonnet, V. Comte, A. Othmane, C. Lagneau, M. Charbonnier, M. Lissac, N. Jaffrezic, Effect of surface topography and chemistry on adhesion, orientation and growth of fibroblasts on nickel-titanium substrates, Materials Science and Engineering C, 21 (2002) 157-165.

28. D.J. Wever, A.G. Veldhuizen, J. de Vries, H.J. Busscher, D.R.A. Uges, J.R. van Horn, Electrochemical and surface characterization of a nickel-titanium alloy, Biomaterials, 19 (1998) 761-769.

29. H. Tian, D. Schryvers, D. Liu, Q. Jiang, J.V. Humbeeck, Stability of Ni in Nitinol oxide surfaces, Acta Biomaterialia, 7 (2010) 892-899.

30. I. Demetrescu, C. Pirvu, V. Mitran, Effect of nano-topographical features of Ti/TiO2 electrode surface on cell response and electrochemical stability in artificial saliva, Bioelectrochemistry, 79 (2010) 122-129.

31. S.A. Bernard, V.K. Balla, N.M. Davies, S.Bose, A. Bandyopadhyay, Bone cell-materials interactions and $\mathrm{Ni}$ ion release of anodized equiatomic NiTi alloy, Acta Biomaterialia, 7 (2011) 1902-1912. 
32. K. Anselme, M. Bigerelle, B. Noel, E. Dufresne, D. Judas, A. Iost, P. Hardouin, Qualitative and quantitative study of human osteoblast adhesion on materials with various surface roughnesses, Journal of Biomedical Material Research, 49 (2000) 156-166.

33. D.D. Deligianni, N. Katsala, S. Ladas, D. Sotiropoulou, J. Amedee, Y.F. Missirlis, Effect of surface roughness of the titanium alloy Ti-6Al-4V on human bone marrow cell response and on protein adsorption, Biomaterials, 22 (2001) 1241-1251.

34. A.P. Serro, A.C. Fernandes, B. Saramago, W. Norde, Bovine serum albumin adsorption on titania surfaces and its relation to wettability aspects. Journal of Biomedical Material Research, 46 (1999) 376-381.

35. D.E. McDonald, B. Markovic, M. Allen, P. Somasundaran, A.L. Boskey, Surface analysis of human plasma fibronectin adsorbed to commercially pure titanium materials. Journal of Biomedical Material Research, 41 (1998) 120-130.

36. D.S. Kommireddy, S.M., Sriram, Y.M. Lvov, D.K. Mills, Stem cell attachment to layer-by-layer assembled $\mathrm{TiO}_{2}$ nanoparticle thin films, Biomaterials, 27 (2006) 4296-4303.

37. P. Van der Valk, A.W.J. van Pelt, H.J. Busscher, H.P. de Jong, C.R.H. Wildevuur, J. Arends, Interaction of fibroblast and polymer surfaces: relationship between surface free energy and fibroblasts spreading, Journal of Biomedical Materials Research, 17 (1983) 807-817.

38. G. Altankov, F. Grinnell, T. Groth, Studies on the biocompatibility of materials: fibroblast reorganization of substratum bound fibronectin on surfaces varying in wettability, Journal of Biomedical Materials Research, 30 (1996) 385-391.

39. K.S. Brammer, O. Seungjan, C.J. Cobb, L.M. Bjursten, H. Van der Heyde, S. Jin, Improved bone-forming functionality on diameter-controlled $\mathrm{TiO}_{2}$ nanotube surface, Acta Biomaterilia, 5 (2009) 3215-3223.

40. Z. Yang, Y. Wu, C. Li, T. Zhang, Y. Zou, J.H. Hui, Z. Ge, E.H. Lee, Improved mesenchymal stem cells attachment and in vitro cartilage tissue formation on chitosan-modified poly(l-lactide-co-epsilon-caprolactone) scaffold, Tissue Engineering Part A, 18 (2012) 242-251. 
41. A. Cunha, A.P. Serro, V. Oliveira, A. Almeida, R. Vilar, M.C. Durrieu, Wetting behaviour of femtosecond laser textured Ti-6Al-4V surfaces, Applied Surface Science 265 (2013) 688-696.

42. K. Anselme, M. Bigerelle, Role of materials surface topography on mammalian cell response, International Materials Reviews, 56 (2011) 243-266.

43. B. Tam, M.I. Khan, Y. Zhou, Mechanical and functional properties of laser-welded Ti-55.8 wt \% Ni Nitinol wires, Metallurgical and Materials Transactions A, 42 (2011) 2166-2175.

44. G.S. Firstov, R.G. Vitchev, H. Kumar, B. Blanpain, J. Van Humbeeck, Surface oxidation of NiTi shape memory alloy, Biomaterials, 23 (2002) 4863-4871.

45. Z.D. Cui, H.C. Man, X.J. Yang, The corrosion and nickel release behavior of laser surface-melted NiTi shape memory alloy in Hanks' solution, Surface and Coatings Technology, 192 (2005) 346-353.

46. C.Y. Zheng, F.L. Nie, Y.F. Zheng, Y. Cheng, S.C. Wei, R.Z. Valiev, Enhanced in vitro biocompatibitity of ultrafine-grained biomedical NiTi alloy with microporous surface, Applied Surface Science, 257 (2011) 9086-9093.

47. Y. Estrin, E.P. Ivanova, A. Michalska, V.K. Truong, R. Lapovok, R. Boyd, Accelerated stem cell attachment to ultrafine grained titanium, Acta Biomaterialia, 7 (2011) 900-906.

48. J.R. Mauney, V. Volloch, D.L. Kaplan. Role of adult mesenchymal stem cells in bone tissue engineering applications: current status and future prospects, Tissue Engineering, 11 (2005) 787-802.

49. M.J. Dalby, N. Gadegaard, R. Tare, A. Andar, M.O. Riehle, P. Herzyk, et al. The control of human mesenchymal cell differentiation using nanoscale symmetry and disorder. Nature Materials, 6 (2007) 997-1003.

50. D. Khang, J. Choi, Y. Im, Y. Kim, J. Jang, S. Kang, T. Nam, J. Song, J. Park, Role of subnano-, nano- and submicron-surface features on osteoblast differentiation of bone marrow mesenchymal stem cells, Biomaterials, 33 (2012) 5997-6007.

51. A.J. Engler, S. Sen, H.L. Sweeney, D.E. Discher, Matrix elasticity direct stem cell lineage specification, Cell, 126 (2006) 677-689. 
52. Y. Liu, X. Yan, Z. Sun, B. Chen, Q. Han, J. Li, Flk-1+ adipose-derived mesenchymal stem cells differentiate into skeletal muscle satellite cells and ameliorate muscular dystrophy in mdx mice, Stem Cell and Development, 16 (2007) 695-706.

53. S. Lavenus, P. Pilet, J. Guichex, P. Weiss, G. Louarn, P. Layrolle, Behaviour of mesenchymal stem cells, fibroblasts, osteoblasts on smooth surfaces, Acta Biomaterialia, 7 (2011) 1525-1534.

54. J. Lincks, B.D. Boyan, C.R. Blanchard, C.H. Lohmann, Y. Liu, D.L. Cochran, D.D. Dean, Z. Schwartz, Response of MG63 osteoblast-like cells to titanium and titanium alloy is dependent on surface roughness and composition, Biomaterials, 22 (2001) 1241-1251.

55. K.W. Jeon, International Review of Cytology: A Survey of Cell Biology, 1st ed., Vol. 262, Elsevier Academic Press, London, UK, 2007, p.119-122.

56. S. Oh, K.S. Brammer, Y.S.J. Li, D. Teng, A.J. Engler, S. Chien, S. Jin, Stem cell fate dictated solely by altered nanotube dimension, Proceedings of the National Academy of Science, 106 (2009) 2130-2135.

57. E.K.F. Yim, R.M. Reano, S.W. Pang, A.F. Yee, C.S. Chen, K.W. Leong, Nanopattern-induced changes in morphology and motility of smooth muscle cells, Biomaterials, 26 (2005) 5405-5413. 


\section{Tables and Figures}

Table 1. Surface roughness parameters of different samples

Table 2. XPS relative concentration (at.\%) of metallic species for different samples

Table 3. XPS surface composition (at.\%) for different samples

Fig. 1. (a-c). SEM backscattered electron images and the corresponding Ni and Ti composition distributions (red for Ni and green for Ti) at (a) MZ, (b) MZ/HAZ boundary and (c) BM

Fig. 2. (a-e). XPS 2p spectra of Ti for different samples

Fig. 3. (a-e). XPS 2p3/2 spectra of Ni for different samples

Fig. 4. (a-j). SEM images showing the morphology of MSCs cultured for 4 hours on different samples

Fig. 5. (a-b). Magnified SEM images for the MZ (as-treated) in Fig. 4. (a) at various magnifications

Fig. 6. (a-j). SEM images showing the morphology of MSCs cultured for 1 day (or 24 hours) on different samples

Fig. 7. Magnified SEM image showing the well-developed intercellular junctions and numerous cytoplasmic projections on the MZ (as-treated)

Fig. 8. Number of viable MSCs cultured for 1 and 4 days on different samples

Fig. 9. Viability of MSCs cultured for 1, 4 and 7 days on different samples 
Table 1. Surface roughness parameters of different samples

\begin{tabular}{|l|c|c|}
\hline \multicolumn{1}{|c|}{ Sample } & $\mathrm{Ra}(\mu \mathrm{m})$ & Maximum peak-to-valley height $(\mu \mathrm{m})$ \\
\hline MZ (as-treated) & $0.375 \pm 0.038$ & $2.49 \pm 0.314$ \\
\hline MZ (ground) & $0.362 \pm 0.031$ & $1.67 \pm 0.243$ \\
\hline MZ (polished) & $0.017 \pm 0.006$ & $0.14 \pm 0.039$ \\
\hline HAZ & $0.289 \pm 0.017$ & $1.46 \pm 0.195$ \\
\hline BM & $0.301 \pm 0.022$ & $1.53 \pm 0.174$ \\
\hline
\end{tabular}

Table 2. XPS relative concentration (at.\%) of metallic species for different samples

\begin{tabular}{|l|c|c|c|c|c|c|c|c|}
\hline \multirow{2}{*}{\multicolumn{1}{c|}{ Sample }} & \multirow{2}{*}{$\mathrm{Ni}^{*} / \mathrm{TiO}_{2}$} & \multicolumn{7}{|c|}{ Relative Concentration of Metallic Species } \\
\cline { 3 - 9 } & & $\mathrm{Ti}^{0}$ & $\mathrm{TiO}$ & $\mathrm{Ti}_{2} \mathrm{O}_{3}$ & $\mathrm{TiO}_{2}$ & $\mathrm{Ni}^{0}$ & $\mathrm{NiO}$ & $\mathrm{Ni}(\mathrm{OH})_{2}$ \\
\hline $\mathrm{MZ}$ (as-treated) & 0.00 & 3.73 & 2.53 & 9.43 & 77.11 & 0.00 & 0.00 & 7.18 \\
\hline $\mathrm{MZ}$ (ground) & 3.60 & 5.76 & 4.08 & 9.12 & 68.71 & 2.48 & 0.21 & 9.64 \\
\hline $\mathrm{MZ}$ (polished) & 12.00 & 7.18 & 7.95 & 9.55 & 60.15 & 7.22 & 0.26 & 7.70 \\
\hline $\mathrm{HAZ}$ & 1.81 & 4.55 & 5.60 & 8.36 & 71.66 & 1.30 & 0.02 & 8.51 \\
\hline $\mathrm{BM}$ & 5.77 & 8.12 & 4.96 & 9.77 & 67.01 & 3.87 & 0.31 & 5.95 \\
\hline
\end{tabular}

Relative concentration of metallic species is calculated by $\mathrm{M} /(\mathrm{Ni}+\mathrm{Ti})$, where $\mathrm{M}$ is individual contribution by the species of interest, $\mathrm{Ni}$ and $\mathrm{Ti}$ are the total contribution by nickel and titanium species respectively

Table 3. XPS surface composition (at.\%) for different samples

\begin{tabular}{|l|c|c|c|c|c|c|}
\hline \multicolumn{1}{|c|}{ Sample } & $\mathrm{Ni} / \mathrm{Ti}$ & $\mathrm{Ti} 2 \mathrm{p}$ & $\mathrm{Ni} 2 \mathrm{p}^{3 / 2}$ & $\mathrm{O} 1 \mathrm{~s}$ & $\mathrm{C} 1 \mathrm{~s}$ & $\mathrm{~N} 1 \mathrm{~s}$ \\
\hline MZ (as-treated) & 0.031 & 9.01 & 0.28 & 31.78 & 56.24 & 2.69 \\
\hline MZ (ground) & 0.065 & 8.65 & 0.56 & 28.86 & 60.31 & 1.62 \\
\hline MZ (polished) & 0.123 & 8.28 & 1.02 & 28.24 & 58.75 & 3.71 \\
\hline HAZ & 0.047 & 8.81 & 0.41 & 30.61 & 59.02 & 1.15 \\
\hline BM & 0.080 & 8.53 & 0.68 & 29.14 & 60.6 & 1.05 \\
\hline
\end{tabular}


(a) MZ

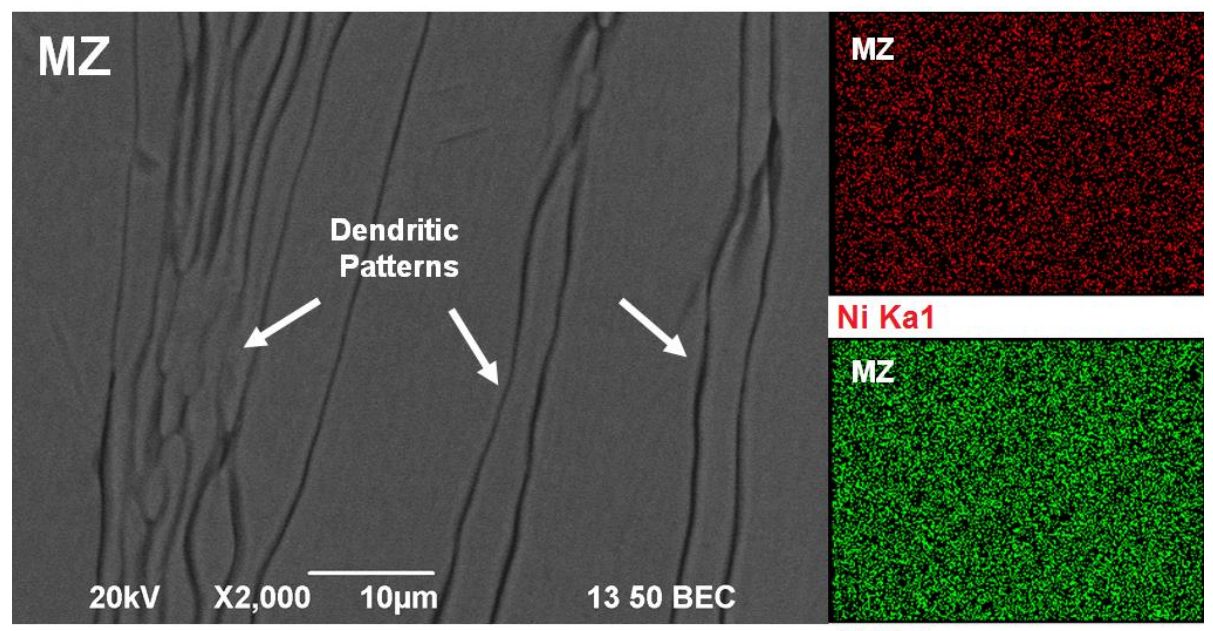

(b) MZ/HAZ Boundary

Ti Ka1

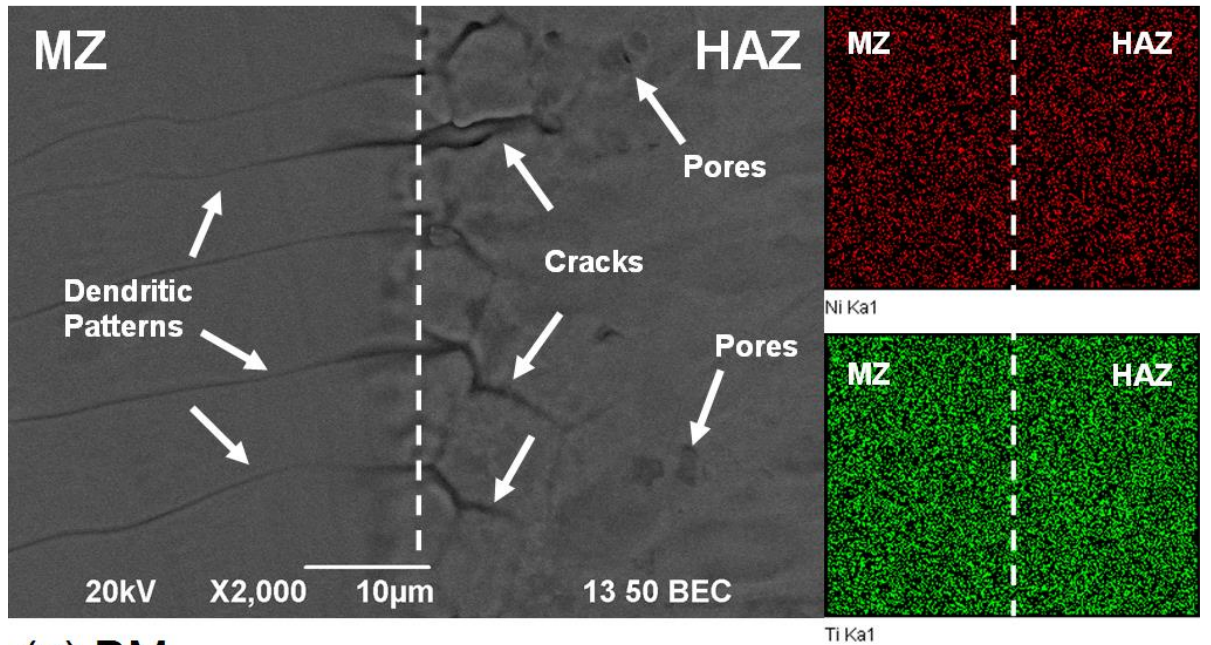

(c) BM
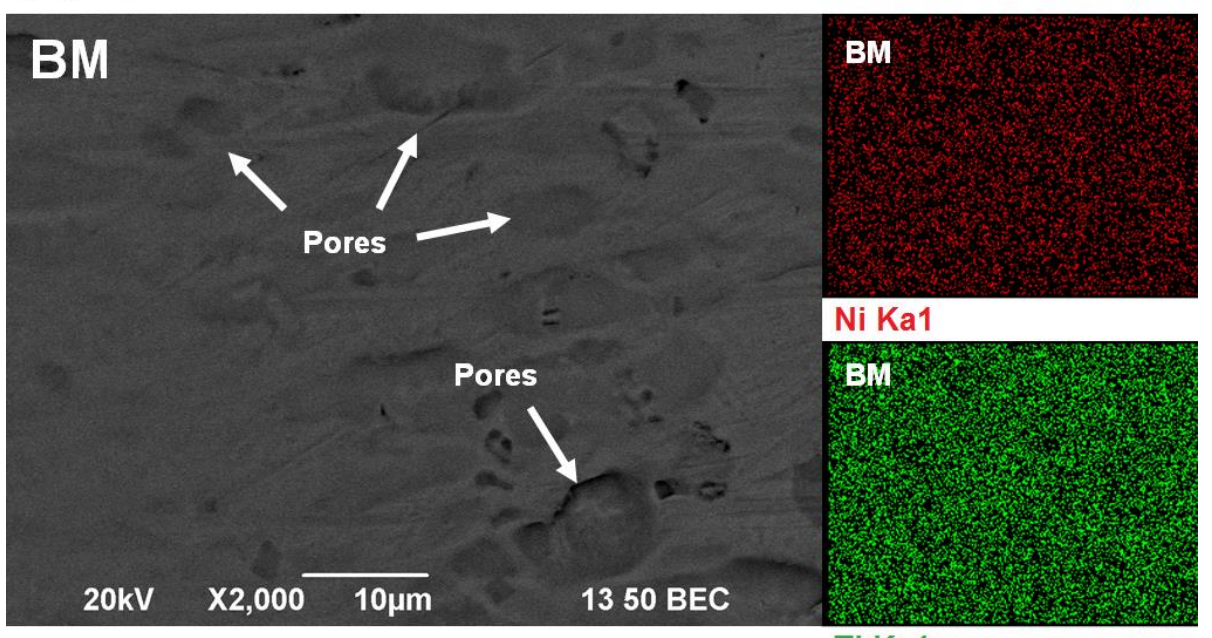

Ti Ka1

Fig. 1. (a-c). SEM backscattered electron images and the corresponding Ni and Ti composition distributions (red for $\mathrm{Ni}$ and green for $\mathrm{Ti}$ ) at (a) MZ, (b) MZ/HAZ boundary and (c) BM 


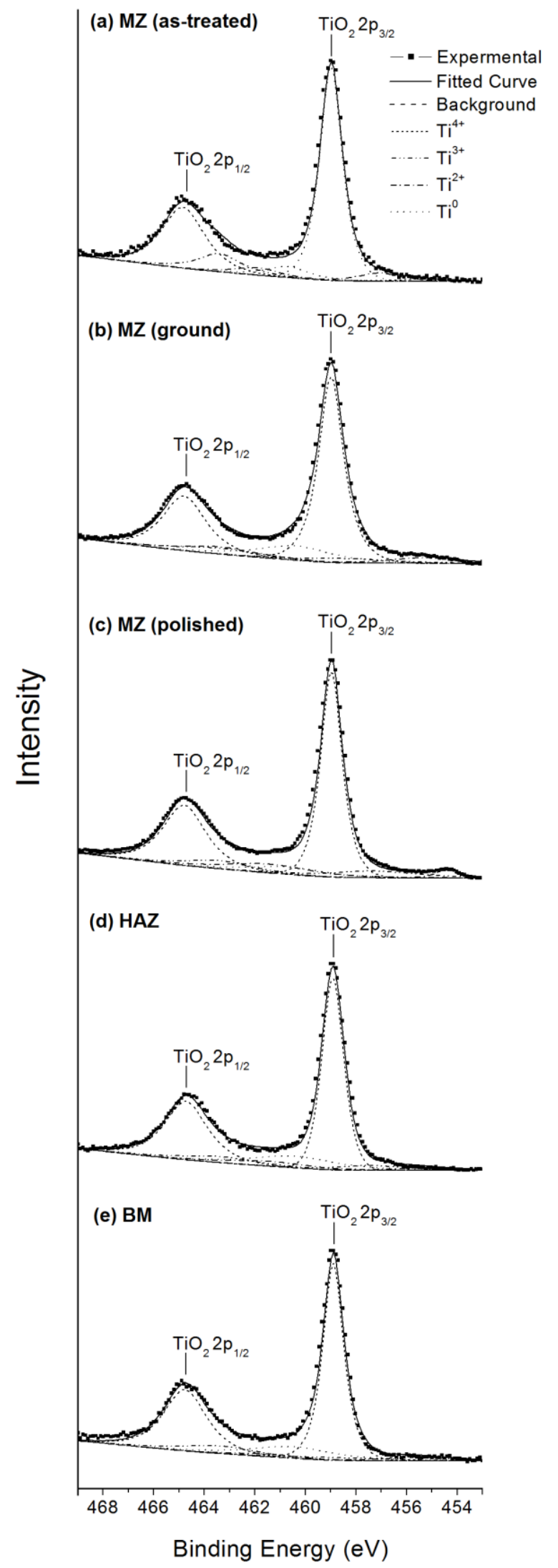

Fig. 2. (a-e). XPS 2p spectra of Ti for different samples 


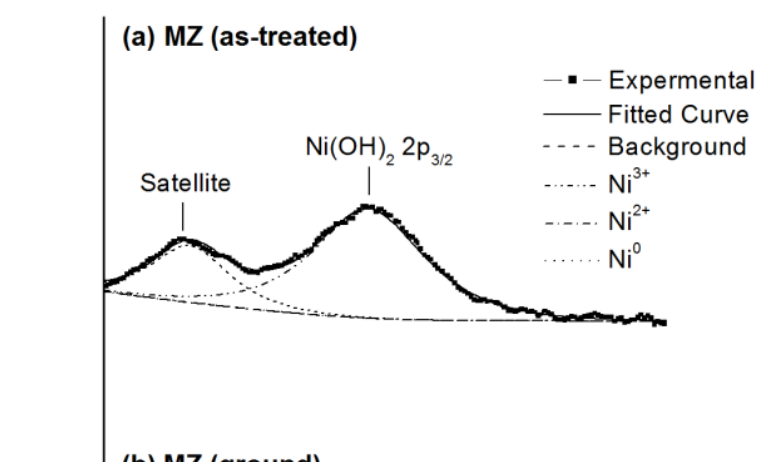

(b) MZ (ground)

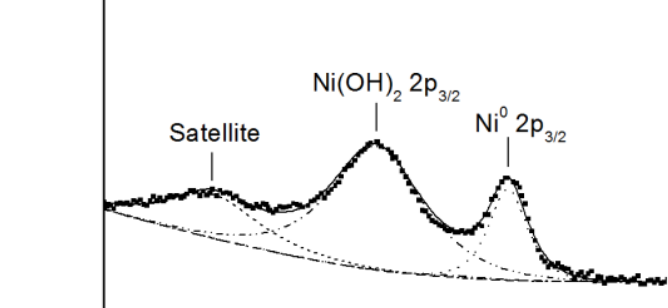

(c) MZ (polished)

童

(d) HAZ

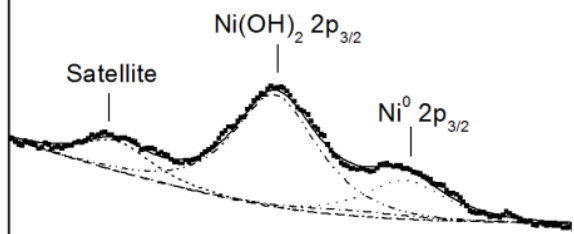

(e) BM

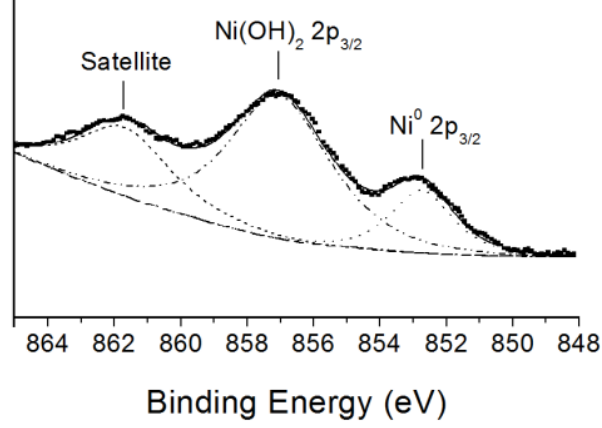

Fig. 3. (a-e). XPS $2 p_{3 / 2}$ spectra of $\mathrm{Ni}$ for different samples 
(a) MZ (as-treated)

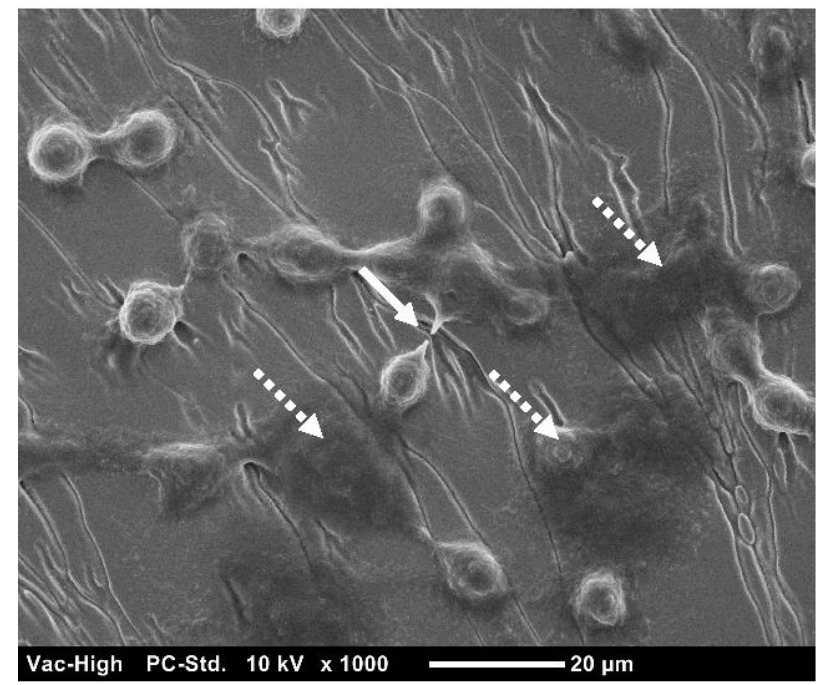

(c) MZ (ground)

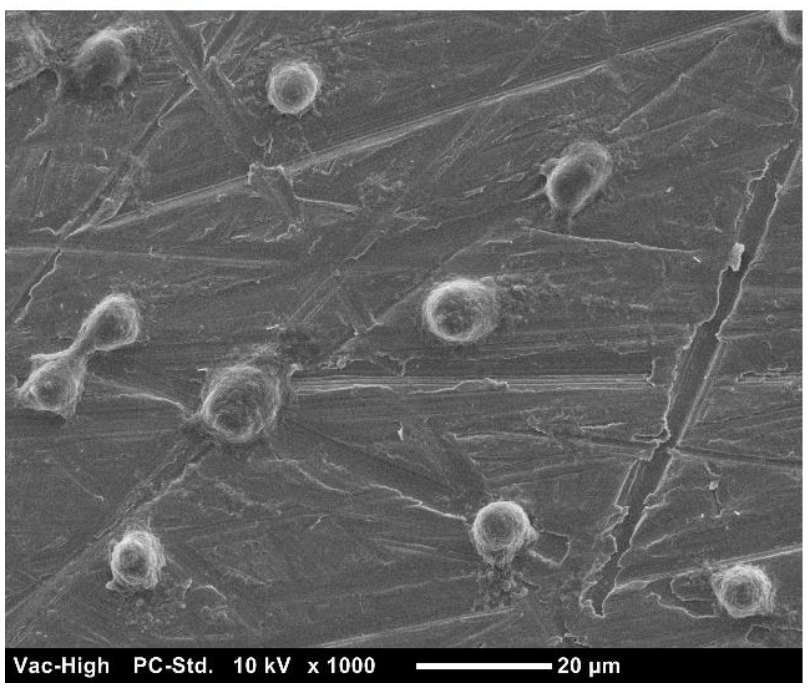

(b) $\mathrm{BM}$

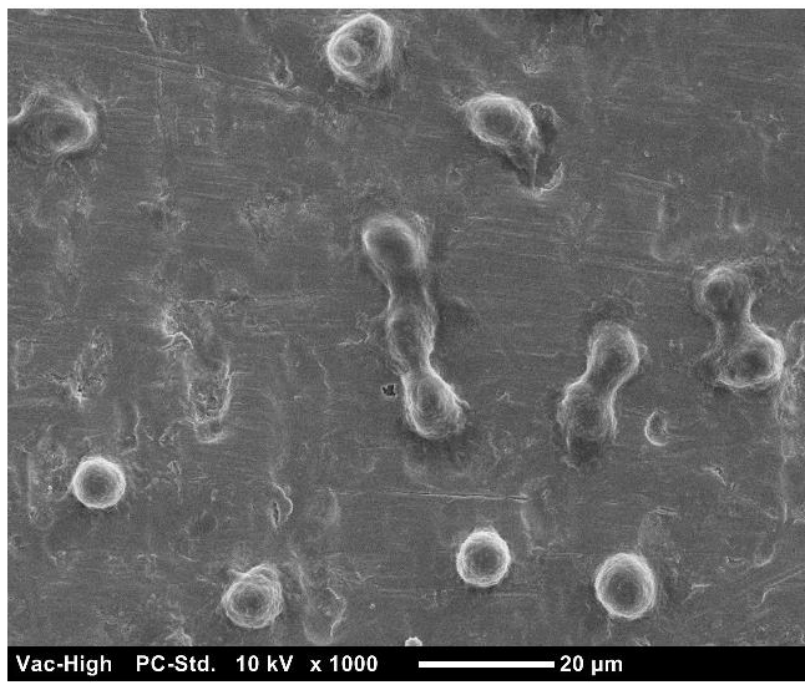

(d) MZ (polished)

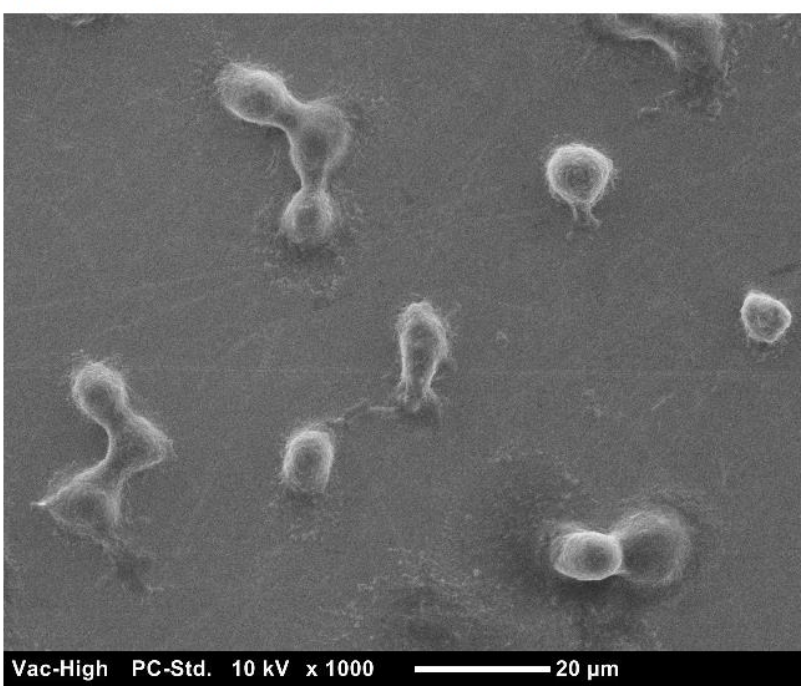

Fig. 4. (a-j). SEM images showing the morphology of MSCs cultured for 4 hours on different samples 


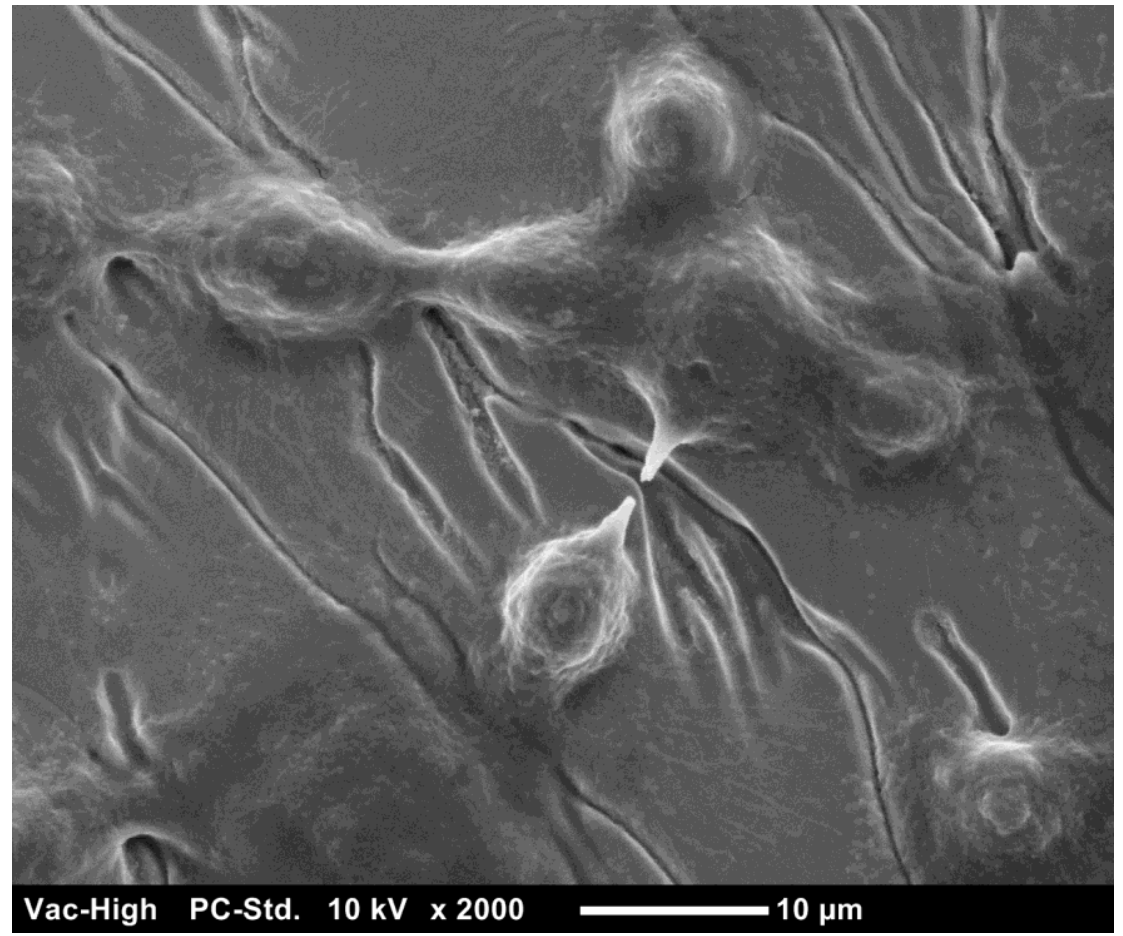

(a) Magnified SEM image for the MZ (as-treated) (at lower magnification)

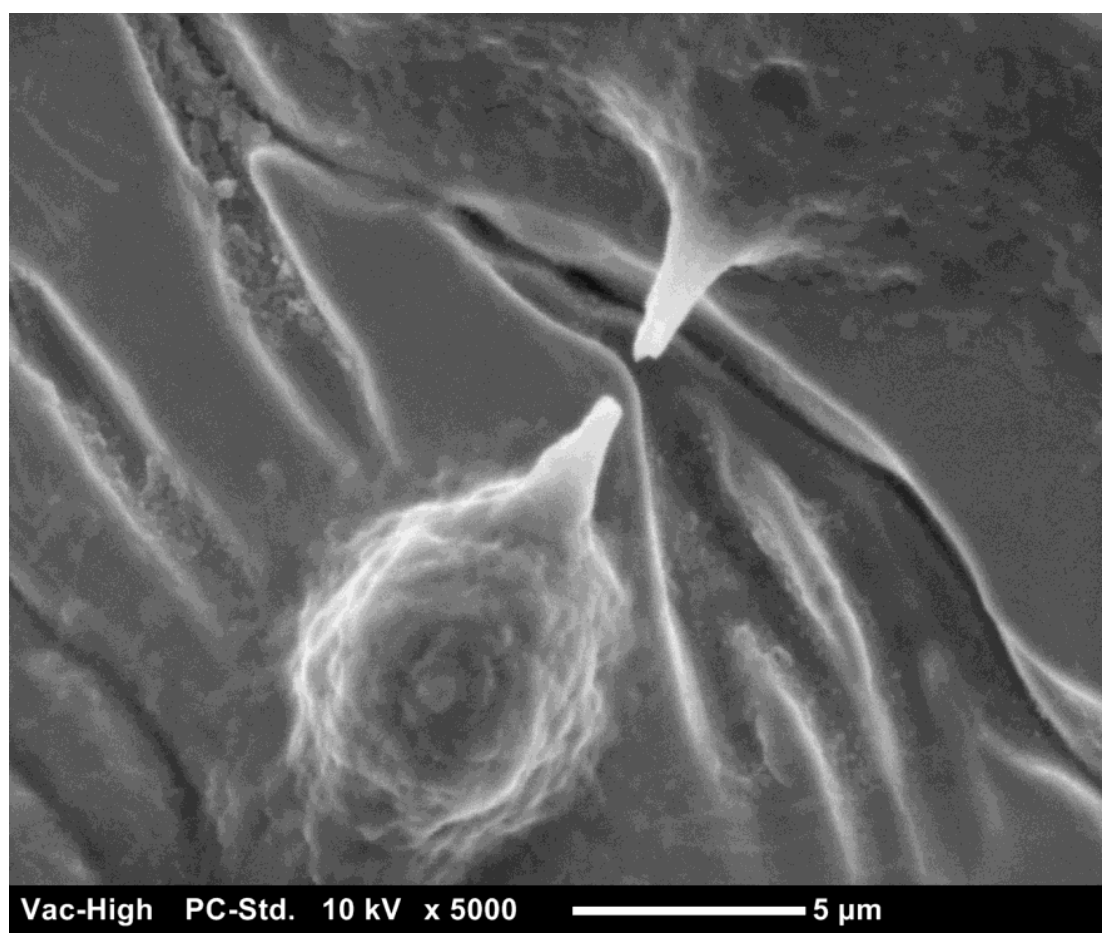

(b) Magnified SEM image for the MZ (as-treated) (at higher magnification)

Fig. 5. (a-b). Magnified SEM images for the MZ (as-treated) in Fig. 4. (a) at various

$$
\text { magnifications }
$$


(a) MZ (as-treated)

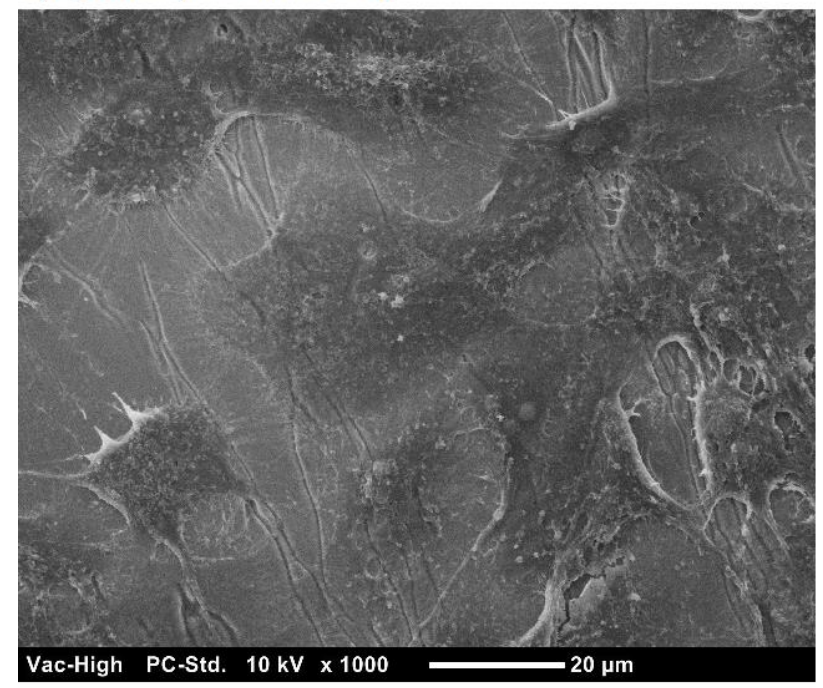

(c) $M Z$ (ground)

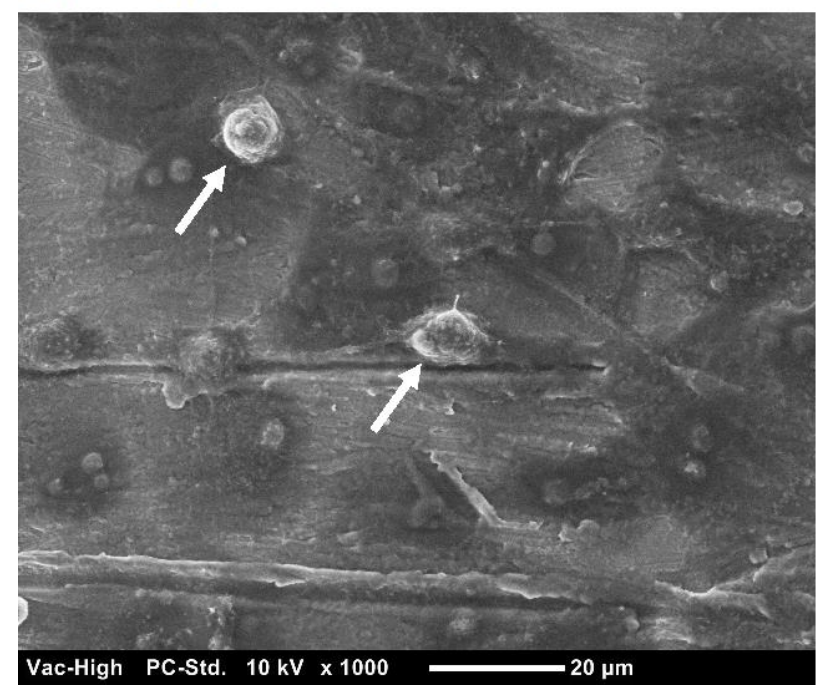

(b) BM

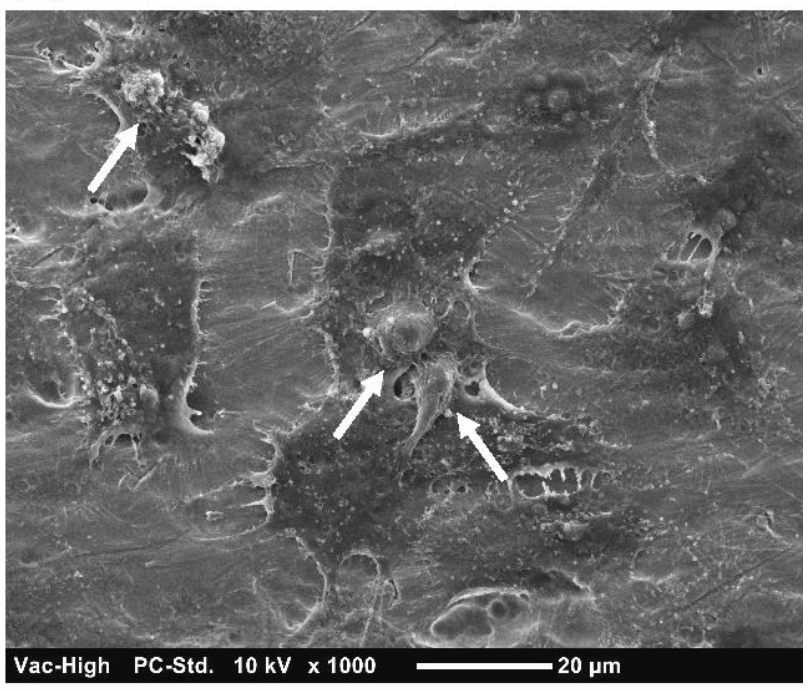

(d) MZ (polished)

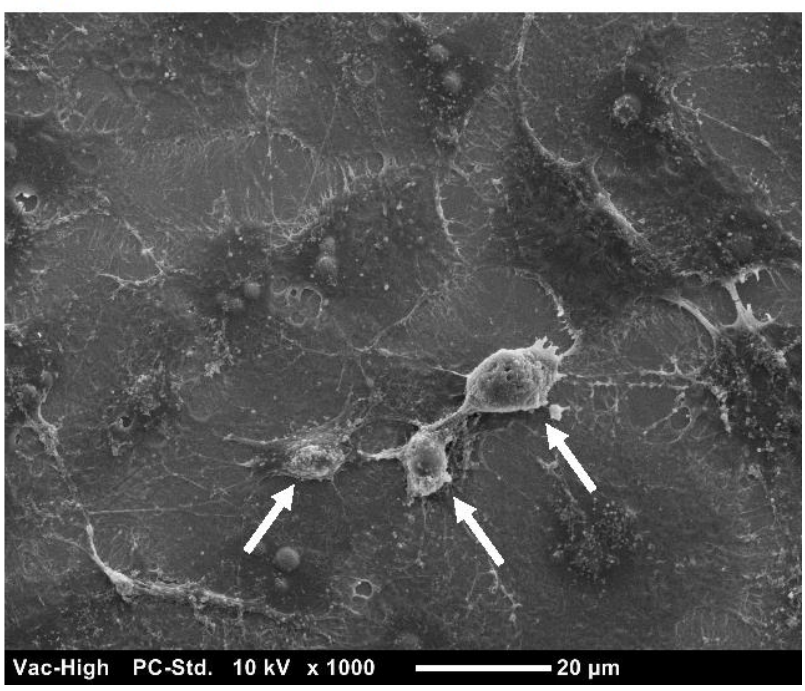

Fig. 6. (a-j). SEM images showing the morphology of MSCs cultured for 1 day (or 24 hours) on different samples 


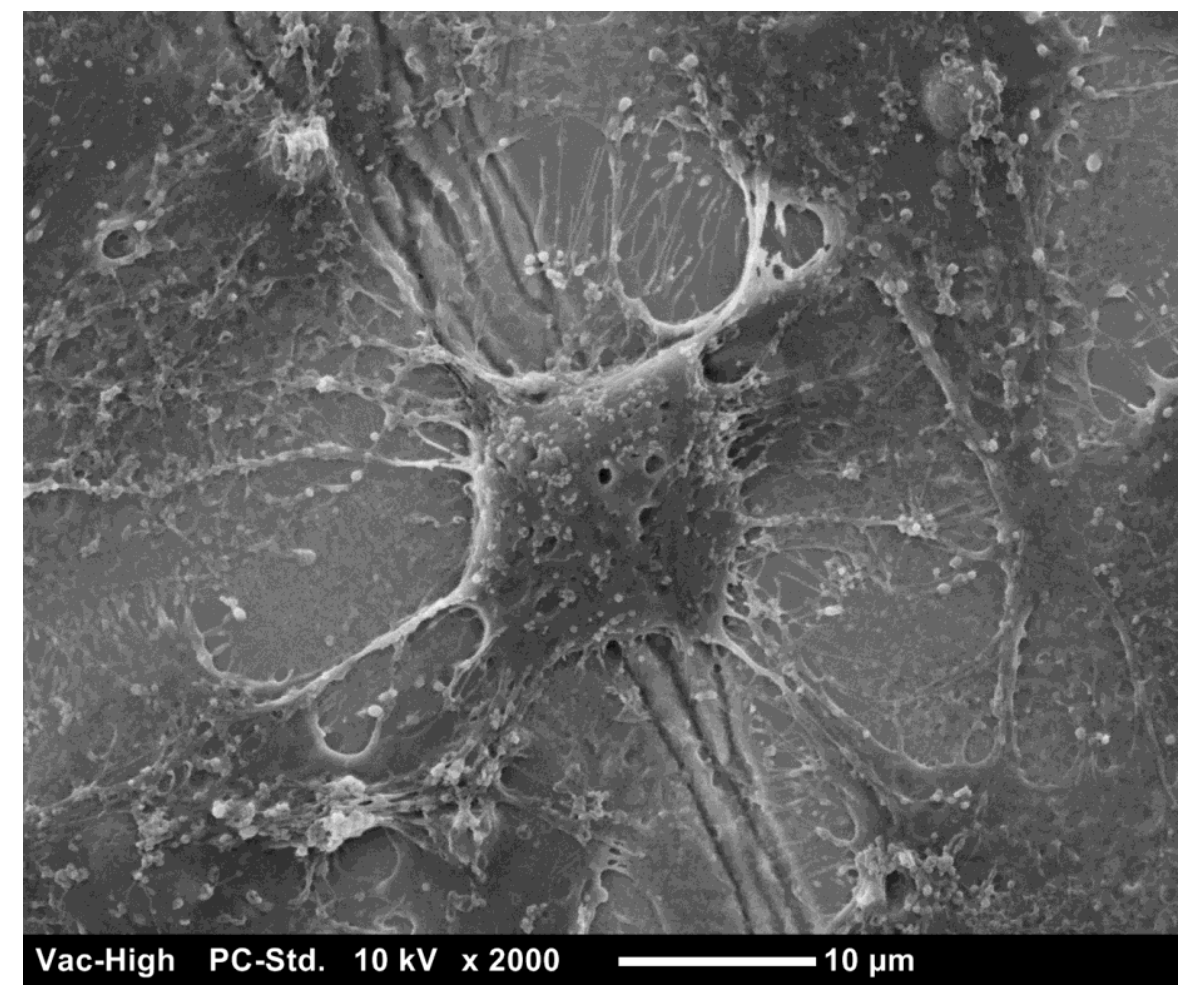

Fig. 7. Magnified SEM image showing the well-developed intercellular junctions and numerous cytoplasmic projections on the MZ (as-treated) 


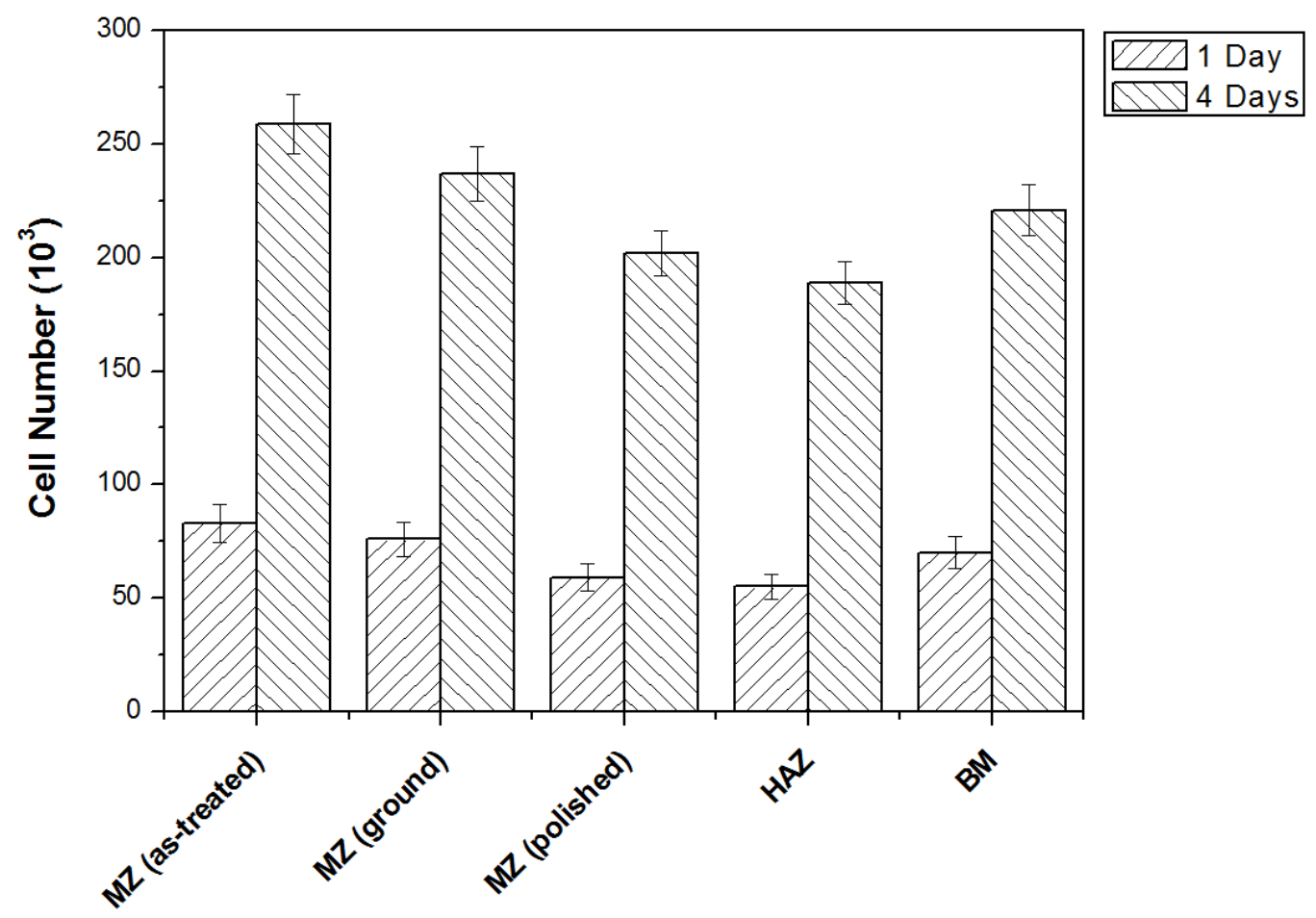

Fig. 8. Number of viable MSCs cultured for 1 and 4 days on different samples

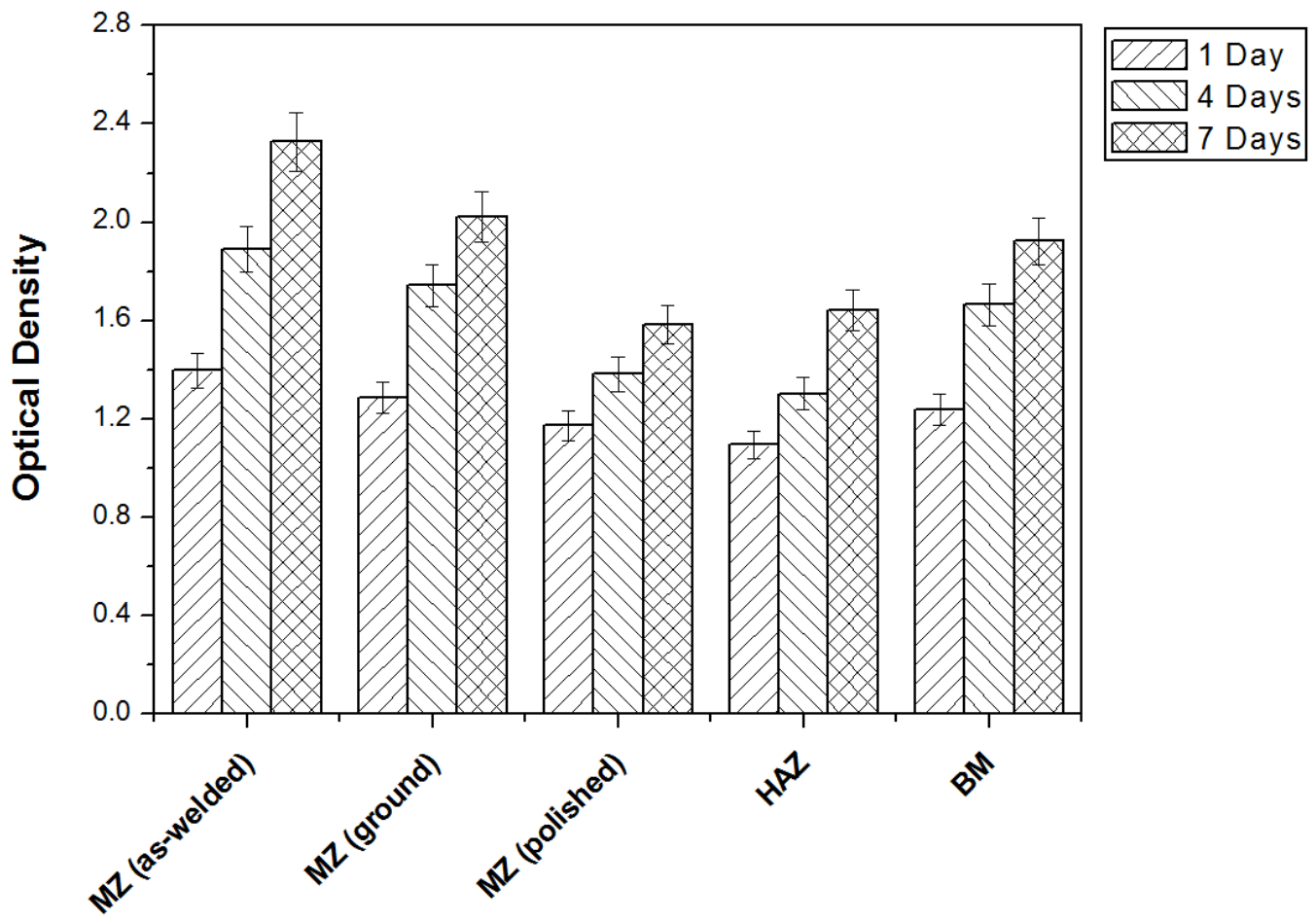

Fig. 9. Viability of MSCs cultured for 1, 4 and 7 days on different samples 